\title{
INFÂNCIA, TELEVISÃO E PUBLICIDADE: UMA METODOLOGIA DE PESQUISA EM CONSTRUÇÃO
}

\author{
RITA MARISA RIBES PEREIRA \\ Faculdade de Educação da Universidade do Estado do Rio de Janeiro \\ Curso de Especialização em Educação Infantil da PUC-Rio \\ ritaribes@uol.com.br
}

\begin{abstract}
RESUMO
Este estudo tem como foco principal a relação estabelecida entre criança e publicidade televisiva. A perspectiva teórica e metodológica é baseada nas idéias de Walter Benjamin, Mikhail Bakhtin e Oliviero Toscani. O objetivo é entender o contexto social e cultural mais amplo no qual essa questão é mantida sob permanente tensão, em especial em razão de algumas mudanças que o marcam acentuadamente: a emergência de novos agrupamentos familiares que, por diferirem dos arranjos nucleares tradicionais, demandam um reordenamento das relações criança-adulto; a desterritorialização do capitalismo e sua concentração no consumo; a fragmentação da vida cotidiana; a construção de uma política de vídeo e a inversão sofrida nos âmbitos públicos e privados; o lugar central hoje ocupado pela mídia e a constatação de que há uma hegemonia das tecnologias eletrônicas e virtuais nos processos de comunicação, bem como a pulverização dos espaços de saber. Nesse contexto, os meios audiovisuais entre eles a televisão - têm compartilhado cada vez mais com a familia e com a escola sua função educativa, ocasionando para ambas um grande desconforto: faz-se necessário, mais do que nunca, repensar o lugar social que ocupam.
\end{abstract}

INFÂNCIA - TELEVISÃO - PROPAGANDA - MÉTODOS DE PESQUISA

\section{ABSTRACT}

CHILD, TELEVISION AND PUBLICITY: A METODOLOGY IN CONSTRUCTING RESEARCH. This research has, as its main focus, the relationship established between child and publicity on TV. The theoretical and methodological perspective is based on the ideas of Walter Benjamin, Mikhail Bakhtin and Oliviero Toscani. The goal is to understand the broader social and cultural context within which this issue is kept under permanent tension. Some important changes have marked it: the emergence of new family groups which, by differing from the traditional nucleus arrangements, asks for the reordering of the child-adult relationship; the loss of a clear delimitation for capitalism and its concentration on consumption; the fragmentation of every-day life; the construction of a video policy and the inversion suffered by the public and private stages; the central place now occupied by the media and the hegemony of electronic and virtual technologies in communication processes. Last, but not least, it is worth to mention the pulverisation of knowledge spaces. Within such context, audio-visual means - television among them - have shared the educational function with family and school, producing a great discomfort for both of them: it is necessary, more than ever, to rethink the social place that these institutions fulfil.

CHILDHOOD - TELEVISION - PUBLICITY - RESEARCH METHODS

Cadernos de Pesquisa, n. I 15, p. 235-264, março/ 2002 
Este estudo tem por objetivo investigar a relação entre a criança e a publicidade televisiva, entendendo que essa relação se apresenta como um desvio metodológico (Benjamin, 1984) para a elaboração de uma crítica da cultura contemporânea. A reflexão que se segue tem como recorte a problematização da relação adulto/criança e dos significados que a cultura midiática - especificamente a publicidade - assume diante dos processos de subjetivação no contexto contemporâneo. Apresenta, ainda, o esboço de alguns princípios teórico-metodológicos para a pesquisa e a intervenção, pautados numa perspectiva de alteridade.

\section{A INFÂNCIA COMO PERSPECTIVA PARA UMA CRÍTICA DA CULTURA}

A velocidade das transformações tecnológicas tem desencadeado significativas alterações não somente nos modos de produção - da economia, da cultura, da arte - mas também nos modos de percepção, gerando assim novas bases para os processos de subjetivação do homem contemporâneo. A gama de possibilidades de atividades cotidianas desdobra-se num fluxo incessante, impondo aos sujeitos uma frenética reelaboração das suas experiências da vida, do tempo, da espacialidade, dos modos de relacionar-se. É certo que essas experiências cotidianas se apresentam indistintamente para adultos e crianças; entretanto, o modo como cada grupo dá sentidos a elas é singular. Para a criança, o desvendamento desse mundo, bem como a compreensão das transformações históricas - seja daquilo que a antecedeu, seja daquilo que testemunha em seu (curto) percurso de vida - encontra-se circuscrito na esfera do lúdico e é atuando nessa esfera que originariamente a criança passa a tomar consciência das suas intervenções e a ressignificar o lugar social que ocupa. Adultos e crianças constroem sentidos em que se implicam mutuamente: como é constituído o mundo que o adulto oferece à criança? Por que o constitui de tal maneira? Quais seus objetivos? Qual o lugar da criança? E o mundo infantil, como se constitui? Qual o lugar nele reservado ao adulto? $\bigcirc$ que dizem um ao outro? $\bigcirc$ que esperam um do outro?

$\mathrm{Na}$ interface dessas indagações, adultos e crianças estabelecem entre si uma relação por natureza de alteridade: impossível compreender isoladamente as transformações dos modos de ser adulto ou de ser criança, uma vez que pensar os desígnios da infância implica necessariamente pensar as condições e os projetos específicos da vida adulta e vice-versa. Essa relação de alteridade envolve um processo histórico e social, cuja origem se situa na consciência da diferenciação entre a infância e a vida adulta, e cujos desdobramentos se expressam nas transformações dos modos como adultos e crianças posicionam-se perante essa diferenciação. Re- 
cuperar o processo dessas transformações apresenta-se como premissa básica para a compreensão da infância como perspectiva para uma crítica da cultura, uma vez que esta implica as mudanças mais globais das sociedades.

Nessa ótica, deve-se pontuar que a construção do conceito moderno de infância esboçou-se num contexto que testemunhou o próprio surgimento e consolidação do capitalismo, trazendo, por isso mesmo, junto de si, amplas e profundas transformações: a organização de agrupamentos familiares mais restritos, os processos de individualização e o surgimento da dicotomia indivíduo-comunidade, a delimitação entre as práticas públicas e as privadas, a substituição das solidariedades coletivas por práticas individualizadas e segmentadas, o desenvolvimento de uma arquitetura voltada ao recolhimento e à introspecção, o pensamento científico assumido como critério de verdade, a hegemonia da leitura e da escrita como tecnologias de comunicação (Ariès, 1981, 1993). Nesse contexto, a criança é vista como dependente do adulto, na medida em que não está, de fato, inserida no processo de produção - central nesse momento do capitalismo - e, por isso mesmo, é tratada como ser incompleto que precisa ser educado sob a lógica desse sistema econômico/cultural. Ainda, a exigência de uma aprendizagem específica para a leitura e a escrita, nesse contexto, não somente deu consciência ao adulto da sua diferenciação em relação à criança, como também fez por reafirmar seu compromisso com a educação, tarefa assumida pela família e pela escola (Postman, 1999). No interior dessas instituições, como pondera Guattari (1987), vamos encontrar - ao longo de sua história - diferenciados sistemas de coerção material, que se estendem desde o castigo e a palmatória até práticas mais amenas como a fila, o falar apenas quando solicitado, a hierarquia etc., necessários ao mundo da vida industrial. Assim sendo, os rituais de iniciação à vida adulta são também os rituais de preparação para o mundo capitalista da produção, bem como para o mapeamento cultural da divisão social do trabalho e das relações de poder.

Reservadas as particularidades das diferentes sociedades e das maneiras como cada uma vem se relacionando com os processos de globalização da economia e da cultura, podemos dizer que, no contexto contemporâneo das sociedades ocidentais, a relação entre adultos e crianças tem sido marcada por um desconforto oriundo da imprecisão dos lugares ocupados pelos indivíduos. Deparamo-nos com uma crescente dificuldade em precisar a linha divisória que separa a infância da idade adulta: por um lado, percebemos a infância marcada por um amadurecimento precoce, envolvida em práticas até então próprias ao adulto, seja trabalho, erotização 
ou criminalidade. Por outro lado, percebemos um adulto que se recusa a amadurecer, respaldado nas promessas da eterna juventude proclamada pela estética do consumo (Kehl, Calligaris, Sevcenko, 1998). Como desdobramento disso, temos um esvaziamento do lugar do adulto no que se refere às suas responsabilidades para com a criança, que, por sua vez, experimenta a controvertida aventura do "virar-se sozinho" (Kincheloe, 200 I; Souza, 2000).

O desconforto que permeia a relação adulto/criança na contemporaneidade, no entanto, não se constitui uma experiência isolada, mas traz no seu entorno os contornos sociopolíticos da lógica do capitalismo tardio ou pós-industrial: desterritorialização do capitalismo e centralização na esfera do consumo, novos agrupamentos familiares distintos dos arranjos nucleares tradicionais, fragmentação da vida cotidiana, inversão das instâncias públicas e privadas, centralidade da mídia, hegemonia das tecnologias eletrônicas e virtuais nos processos de comunicação, pulverização dos espaços de saber (Jameson, 1996; Sarlo, 1997).

Na sociedade de consumo (Baudrillard, 1995), a criança não mais é colocada como dependente do adulto, seja no âmbito mais amplo da esfera econômicopolítica, seja no plano mais restrito da vida familiar e escolar, mesmo porque o lugar que o mercado concedeu para a criança tem sua história intimamente ligada às transformações das relações entre adultos e crianças. Olhada inicialmente como filho de cliente que se relacionava com o mercado a partir do uso de bens materiais e culturais que se ofereciam a ela à margem da sua opinião, a criança é elevada ao status de cliente, isto é, um sujeito que compra, gasta, consome e, sobretudo, é muito exigente. Tão exigente que o mercado se moldou a ela, em nome de formar, desde cedo, um cliente fiel: carrinhos de supermercados em tamanho pequeno, shoppings dedicados somente a crianças, espaços destinados para festas, o "reconhecimento" do seu lugar privilegiado de ser protagonista e espectador dos anúncios publicitários (Capparelli apud Garcia et al., 1996).

Tais transformações dos modos de ser e de relacionar-se devem-se, segundo Guattari ( 1987), ao fato de que a modelagem da infância pelo mundo adulto tem sido pautada cada vez mais pelas semióticas dominantes por ele engendradas e se tem limitado ao domínio das técnicas - de aquisição da linguagem, escrita, desenho etc. -, sem levar em consideração as questões micropolíticas que a constituem. Com isso, os rituais de iniciação aos meandros da vida adulta não mais se circunscrevem a períodos precisos ou cerimoniais, mas se efetivam em tempo integral. $\bigcirc$ autor salienta que a iniciação deixa de ser uma experiência interpessoal orientada pelas demandas da vida adulta e pelas aprendizagens por elas implicadas e se transforma num processo de 
...iniciação ao sistema de representação e de valores do capitalismo que não mais põe em jogo somente pessoas, mas que passa cada vez mais pelos audiovisuais que modelam as crianças aos códigos perceptivos, aos códigos de linguagem, aos modos de relações interpessoais, à autoridade, à hierarquia, à toda a tecnologia capitalista das relações dominantes. (Guattari, 1987, p.5I)

Os sistemas de coerção, hoje, colocam-se no plano simbólico e revelamse, segundo o autor, tanto pela inibição da capacidade de expressão quanto pela adaptação aos valores e comportamentos dominantes, iniciação esta que se dá no campo da linguagem e se apresenta à criança cada vez mais cedo.

\section{PELA TELA, PELA JANELA: O MUNDO NA VITRINE}

Letreiros, luminosos, logotipos, outdoors, bancas de revistas, slogans, marcas, panfletos, gingles, imagens, sedução. Na sociedade de consumo a cidade se oferece em forma de vitrine e ser cidadão é habitar esse mundo com o desprendimento de quem vai às compras. Esse desprendimento, mais que revelar uma simples sensação, é denunciador do quanto a cultura do consumo, como expressão do capitalismo pós-industrial, tem levado a efeito sua intenção educativa. Essa educação não mais se restringe à família e à escola - embora também aconteça no interior destas -, mas expande-se a todas as esferas da vida cotidiana, desde os discursos interpessoais até às formas tecnológicas mais complexas da comunicação humana, entre as quais, especificamente, destacamos as imagens técnicas e os audiovisuais em geral. Diferentemente da linguagem escrita, pautada numa lógica linear e num modelo de abstração conceitual, cuja aprendizagem situa a criança como dependente do ensinamento do adulto, o mundo das imagens técnicas e dos audiovisuais não exige nenhuma formação prévia para o seu desvendamento, ainda que implique maneiras novas de produção e recepção. A seriação, o choque, a descontinuidade, a sobreposição, a simultaneidade, a virtualidade, a hiper-realidade etc. são elementos paradigmáticos da cultura desencadeados pela fotografia e pelo cinema, cujas mudanças operadas talvez só se façam perceber hoje com as tecnologias eletrônicas e digitais, seja na televisão ou no ciberespaço (Machado apud Flusser, 1998). Enquanto para o adulto tais transformações tecnológicas se apresentam filosoficamente como um problema e implicam sempre uma readequação dos modos de pensar e de viver, para a criança elas se apresentam como constituintes quase que imediatas da sua vida psíquica e tomam a forma de brinquedo a ser explorado de maneira lúdica (Flusser, 1998; Souza, 2001). 
A desenvoltura com que a criança lida com as "eternamente novas" tecnologias audiovisuais não somente a coloca numa posição de independência diante do adulto, como a transforma na tradutora, para o adulto, dos significados de uma criação que é sua (adulto) mas que a ele próprio ainda soa como estranha. É certo que isto pode ser compreendido como uma forma nova de diálogo entre adultos e crianças para além da histórica relação de dominação. Entretanto, não se pode deixar de considerar que, juntamente com isso, está sendo colocado em xeque o próprio conceito de experiência, que tende a se desvincular da tradição (Benjamin, 1987) e a associar-se cada vez mais ao domínio das técnicas. Quais as conseqüências éticas que podemos extrair dessa nova condição? Que princípios filosóficos, econômicos e sociais estão lhe servindo de base? Como se constituem a alteridade, a identidade, o afeto? Como se põe em questão a incompletude do nosso olhar, a necessidade de um outro que nos confirme e nos desafie? Se uma das características da cultura humana é a transmissão das descobertas da humanidade para as gerações vindouras, para que estas as possam colocar sob o crivo de sua época e se lançar a novos desafios, o que podemos esperar de uma geração condenada a buscar por si própria suas respostas? Em que lugares encontrar essas respostas?

É no bojo dessas questões que a televisão, como a mais popular forma de mídia, assume um papel fundamental, não somente no que se refere à relação adulto/criança, mas em praticamente todas as áreas da vida humana - na arte, na produção de conhecimento, nas ideologias, na política. Presente hoje em mais de 98\% das residências brasileiras (muitas vezes com mais de um aparelho em cada casa) a televisão transformou-se em referência simbólica dos sujeitos contemporâneos. Como pondera Bucci,

....a televisão é muito mais do que um aglomeramento de produtos descartáveis destinados ao entretenimento de massa. No Brasil, ela consiste num sistema complexo que fornece o código pelo qual os brasileiros se reconhecem brasileiros. Ela domina o espaço público (ou a esfera pública) de tal forma, que, sem ela, ou sem a representação que ela propõe do país, torna-se quase impraticável a comunicação e quase impossível o entendimento nacional.[...] O espaço público, no Brasil, começa e termina nos limites postos pela televisão. [...] O que é invisível para as objetivas da TV não faz parte do espaço público brasileiro. O que não é iluminado pelo jorro multicolorido dos monitores ainda não foi integrado a ele. (1997, p.9-1 I)

A televisão é uma janela para o mundo e também uma janela sobre o sujeito (Hoinef, 1995). Pela tela chegam sucessivas informações que exigem um olhar cada 
vez mais desprendido: informações sobre o mundo, modelos de comportamento, um guia prático cultural. Mais que isso, entretanto, a tela passa a ser um lugar almejado. Sob a lógica da videopolítica (Sarlo, 1997), visibilidade e fama tanto podem apresentar-se como possibilidades de redenção e de poder como podem transformar-se em prática de controle num contexto marcado pela desigualdade social e pela completa inversão das esferas públicas e privadas.

"A televisão não existe ainda como objeto de pesquisa." A crítica feita por Moreira (2000) refere-se especificamente à inexistência de uma história sistematizada da televisão brasileira. Segundo o autor, a escassa bibliografia existente tem-se dedicado basicamente a narrativas memorialísticas ou biografias de personalidades. No que se refere à elaboração de uma análise crítica sobre a televisão, as origens institucionais das pesquisas e as especifidades dos enfoques têm desenhado um quadro muito amplo e pulverizado, impedindo uma reflexão mais complexa. Como exemplo disso, podemos citar o descompasso entre as inúmeras pesquisas de caráter eminentemente pragmático, feitas no meio televisivo, e as pesquisas acadêmicas bastante centradas na programação ou nos possíveis efeitos da televisão na psique e que nem sempre conseguem escapar a um olhar maniqueísta. Esse descompasso faz com que a televisão, na sua complexidade, continue a ser um objeto não pensado, constatação presente também nas reflexões de Baudrillard (1993), Wolton (1990), Bazalguete e Buckingan (1995), Kehl (199|, 2000) e Sampaio (2000). Uma análise crítica da televisão, pondera Bucci,

...não pode se acomodar à crítica de obras isoladas no interior da programação, por mais que admitamos a existência de gêneros no interior da TV. [...] Acima dos gêneros, a crítica da televisão é a crítica de um novo patamar das relações sociais e das relações ideológicas entre os sujeitos, e só a partir daí ela ganha seu sentido político - o que mais interessa. [...] A crítica da televisão não lida (apenas) com a estética. Ela não tem por objeto uma arte, mas um fato social como a própria língua (ou como a linguagem). Portanto, deve declarar que, discutindo a cultura, está discutindo a sociedade e seus sujeitos. A crítica da televisão, hoje, é uma crítica do poder. (Martins, 2000, p. 37)

Ampliando as exigências apontadas por Bucci para a construção de uma crítica efetiva da televisão, Moreira (2000) sugere outros elementos a serem levados em consideração, tanto no âmbito da comunicação social como também entre pesquisadores de outros segmentos da sociedade: as relações sociais que permeiam a produção televisiva, a fim de mapear, nos diferentes momentos históricos, quem 
a faz e por que é feita; a construção de um inventário sobre a programação televisiva que permita compreender não somente as transformações históricas dos tipos de produção como também as suas formas de recepção; a relação que a produção televisiva mantém com outras formas de produção tecnológicas e artísticas, como, por exemplo, o cinema; a contextualização da televisão na história das telecomunicações, do ponto de vista político e tecnológico; o uso dos avanços tecnológicos não apenas para uma qualificação do que está em produção, mas também para a recuperação do acervo histórico existente; uma análise da programação televisiva a partir de suas articulações internas e estratégias de significação, buscando a origem de seus estilos e a contextualização destes no cenário cultural mais amplo; enfim, a sistematização de uma história da televisão que articule seus aspectos técnicos e políticos, que, em última instância, é também a história das relações sociais testemunhadas ou engendradas por esse aparato tecnológico.

Entretanto, mesmo que não disponhamos de uma história concisa da presença da televisão no Brasil, podemos nos aventurar, ainda que de maneira esparsa, a reconstituir sua história, tendo como desvio metodológico a história da relação da criança com a televisão no Brasil, construída ao longo de 50 anos. Apresentando inicialmente sua programação ao vivo e no período noturno, dirigia-se basicamente aos adultos. A elaboração de uma programação infantil - baseada em clássicos da literatura universal ou em concursos de conhecimentos gerais - foi a primeira forma de inclusão da criança no universo do "público televisivo". Seduzida por esse novo objeto mágico que passava agora a falar para ela, e com uma linguagem tão lúdica quanto a das suas brincadeiras (Brougère, 1995), a criança passou a subverter algumas regras familiares, protelando cada vez mais os horários estabelecidos para ir dormir. Curiosamente, ainda na década de 50, a própria emissora de televisão (Tupy), como resposta ao desconforto manifestado por algumas famílias, assumiu seu papel de nova autoridade e deu às crianças o seu recado: embaladas por um ging/e infantil, o filme de animação anunciava a hora de dormir. Anunciava ainda que sua linguagem não admitia contestação, diferentemente de todos os discursos que os familiares ao redor pudessem proferir. Juntamente com outros incontáveis sons e imagens, esse ging/e passou a fazer parte do imaginário infantil, não se diferenciando de qualquer outra canção da cultura popular que tradicionalmente velava o sono infantil (Fanucchi, 1995; Rixa, 2000).

Algumas mudanças qualitativas da relação entre a criança e a televisão merecem destaque. Uma primeira, deu-se nos anos 60, no momento em que a criança deixou de ser apenas espectador e passou a ser também protagonista dos programas exibidos. Inicialmente com participação restrita à programação infantil 
ou a espetáculos de cunho artístico e cultural, a criança tornou-se aos poucos uma imagem bastante presente. Uma segunda mudança diz respeito à criação de um novo conceito de programa infantil, não mais pautado em histórias da literatura ou em apresentações artísticas, mas em animação e gincanas. Esse novo formato, padronizado a partir dos anos 80, faz da apresentadora do programa sua figura central e confere à criança um novo lugar no espaço midiático: transformada em cenário, ela se alterna entre a imobilidade de ser um mero "pano de fundo" e o incessante e desconexo movimento das danças coreografadas, brincadeiras competitivas que valem prêmios, degustação ou exibição de produtos de empresas que patrocinam o programa. Paralelamente, cria-se um mercado de produtos vinculados aos programas e à figura das apresentadoras, que variam desde bonecas e estampas em vestuário até aparelhos eletrônicos, utensílios domésticos e alimentos, e ajudam a consolidar, junto à criança, o status de consumidor. Por fim, uma terceira mudança significativa está ligada ao surgimento de emissoras de televisão especificamente dedicadas ao público infantil, todas de canais por assinatura, na sua maioria estrangeiros e veiculados em países com distintos fusos horários, durante as 24 horas do dia. Passados muitos anos da vinheta que nos avisava a hora de dormir, esses canais -, ao contrário, independentemente do horário, nos interpelam a não sair da frente da televisão, seja de maneira lúdica, com charadas ou anúncio de outros programas, seja pela explicitação de um argumento de autoridade: "Não sai daí! A gente volta já!".

Independentemente das especificidades de público das TVs por assinatura e as ditas abertas, a TV é o meio de comunicação preferido pelas crianças (88\%), que a assistem em média três a quatro horas diárias (Moreno, 1992), interagindo muitas vezes com esse objeto como se fosse um semelhante seu. Embora essa média seja variável em diferentes países, conforme aponta recente pesquisa organizada pela Unesco, o tempo dedicado à televisão chega muitas vezes a ser superior em até $50 \%$ ao dedicado a outras atividades da criança, entre elas fazer dever de casa, ajudar a família, brincar fora de casa, ler, usar o computador, ouvir rádio, fitas ou CDs (Carlsson, Von Feilitzen, 2002). Ocupando tempo e espaço cada vez mais centrais tanto na vida da criança quanto na do adulto, a televisão acaba por preencher um lugar deixado vazio: o do diálogo. Essa tem sido uma das afirmações trazidas por Postman ( 1 999), que vê na televisão o aparato tecnológico que fomenta o desaparecimento da infância, isto é, o desaparecimento da consciência da diferenciação entre adulto e criança. Segundo o autor, esse instrumento tecnológico é responsável pelo apagamento de algumas práticas fundamentais para a delimitação dos lugares sociais da criança e do adulto, a exemplo das per- 
guntas essenciais do ser humano, ligadas ao seu nascimento e morte e também aos mistérios da vida. Postman pondera que cabia ao adulto a responsabilidade de administrar ao longo da vida da criança os momentos mais adequados de responder a essas perguntas; em contrapartida, o adulto significava para a criança uma referência para a busca de respostas às suas indagações. Com isso, alguns temas tornavam-se motivo de segredo e até mesmo de vergonha, exigindo rituais apropriados para a sua abordagem. Com a maciça presença da televisão na vida cotidiana, esse quadro se modificou. Mais do que deixar de reconhecer no adulto uma referência para a busca de repostas, trata-se da inexistência das indagações, uma vez que a televisão - que fala a todos, sobre todos os temas, num único tom - oferece respostas para perguntas que nem chegaram a ser feitas.

Compactuando com a técnica narrativa de Xerazade, os programas de TV também interrompem sua história no ponto culminante, adiando o desenredo da história para depois do intervalo comercial. Seu volume sonoro perceptivelmente mais elevado que o do restante da programação é como uma autorização para que possamos sair da frente da TV, sem que, para isso, deixemos de ser olhados por ela. Entretanto, tem ficado cada vez mais difícil precisar esses distintos momentos, uma vez que os anúncios foram admitidos no interior dos programas em forma de merchandising, assim como os programas não se têm diferenciado muito dos filmes publicitários. Até mesmo protagonistas/apresentadores, seu modo de ser ou seu estilo de vida transformaram-se em objeto de consumo, pulverizando os apelos publicitários nas minúcias da vida cotidiana e transformando os sujeitos em anúncios ambulantes, como bem ressalta a poesia de Drummond:

... desde a cabeça até o bico dos sapatos, são mensagens, letras falantes, gritos visuais, ordem de uso, abuso, reincidência, costume, hábito, premência, indispensabilidade, e fazem de mim homem-anúncio itinerante, escravo da matéria anunciada'.

A publicidade, pondera Toscani (1996a), nasceu de um antigo flerte entre a arte e o mercado. Entretanto, num contexto em que a própria arte foi assumindo a forma de mercadoria, a publicidade acabou por aderir à lógica do mercado, consolidando-se como um discurso de adesão ao consumo. Esquecendo-se de sua dimensão artística, a publicidade vem abrindo mão da capacidade de refletir sobre o mundo em prol da incessante busca de uma boa idéia, confinando-se às

I. Extraído do poema "Eu Etiqueta", de Carlos Drummond de Andrade ( 994$)$. Disponível em: www.suigeneris.pro.br/contos38.htm 
leis do mercado. Nessa ótica, a publicidade autorizou-se a criar, dentro de seus limites, como que uma outra sociedade, uma sociedade em que todos são felizes, a vida tem mais cor, cada um fica na sua, com a certeza de ter alguma coisa em comum. "Somente esse universo mágico é capaz de unir sucesso e cigarro, ecologia e conjunto habitacional, margarina e saúde infantil, batom e beleza do eterno feminino. [...] É lá o lugar em que eu tudo compro e nada devo, e tudo sobra, nada falta. [...] Os descontos anulam gastos, e, pagando, na verdade, economizo" (Rocha, 1995, p. 32). Mas essa "sociedade lá dentro" invade nosso cotidiano, deixando-nos muitas vezes na dúvida do lugar que ocupamos. Desejamos ser admitidos como seu personagem, metamorfose nada difícil para o homem contemporâneo que anestesia a angústia ou a depressão no simples ato de consumir: a vida real passa a ser cada vez menos real.

Vista de outro modo, porém, a publicidade tende a revigorar sua origem artística à medida que passa a assumir alguns papéis até então reservados à arte, entre eles, o de ser uma produção representativa de uma época, como pontua Lipovetsky (apud Toscani):

Onde era possível encontrar a provocação no século passado? Seguramente na arte. E hoje? As vanguardas artísticas pararam de fazer escândalo. Onde está então a transgressão? Paradoxalmente, na expressão mais reconhecível do capitalismo: a publicidade. (1996, p. 57)

Numa posição vanguardista, a publicidade tem assumido o papel de ser tradutora de uma época, no entanto, essa tradução tem sido feita à margem da reflexão, num discurso genericamente uníssono que a descaracteriza como arte. Exigir-Ihe outro discurso seria uma forma de reabilitar sua dimensão artísica? É a publicidade uma produção artística?

Na história brasileira, a publicidade surge juntamente com a criação da imprensa, há cerca de 200 anos (Ramos, Marcondes, 1995). Inicialmente consistia na descrição minuciosa de um serviço ou produto colocado à venda, conforme mostram os anúncios classificados dos antigos jornais. Esses anúncios, por um lado, dão a perceber toda a experiência temporal de uma época menos apressada, revelada na infinidade dos detalhes apresentados; por outro, deixam à mostra o avesso de uma sociedade que, nos mesmos anúncios classificados, vendia e comprava, sem distinção, cestos, casas, cavalos e escravos - adultos e crianças. Os anúncios apresentavam-se como comunicados, sem intenção de persuasão, como denuncia a chamada "para quem quiser", recorrente em quase todos os 
anúncios da primeira metade do século XIX. Aos poucos, passaram a articular textos (ainda extensos) com imagens ilustrativas, geralmente caricaturas, arte muito em voga na virada do século XIX para o XX. Jornais, revistas, almanaques, pasquins, cartazes, calendários, folhinhas. A publicidade do século $X X$ estrutura-se com imagens coloridas, caráter persuasivo e uma linguagem de prontidão(Benjamin, 1987; Pasolini, 1990), expressa nos gingles e principalmente nos slogans. Cinema, rádio, televisão, multimídias. Experimentando diferentes formas, suportes e linguagens, a publicidade brasileira foi incorporando e redefinindo inúmeros aspectos da cultura brasileira - marcas, produtos e linguagens que contam nossa história: as relações com o estrangeiro, as políticas higienistas, as correntes artísticas e os padrões estéticos de cada época, enfim, os modos como cada época se descrevia. Podemos ver nessa forma de descrição, o que Lipovetsky ( 1999) aponta como uma outra perspectiva de produção histórica, tendo por base não mais os aspectos duradouros da cultura, mas o que ela tem de mais efêmero.

Já consolidada nas ondas do rádio, a publicidade começou a ser veiculada na televisão de maneira tímida, tanto porque as técnicas e os recursos necessários para a construção das peças audiovisuais ainda eram desconhecidos dos profissionais da publicidade quanto pela incerteza das empresas em oferecerem seus produtos nesse meio ainda muito novo. Assim, do mesmo modo que a programação das rádios foi transposta para a televisão, a publicidade conquistou o espaço da tela e lançou uma figura muito particular: a garota propaganda, que continuava a apresentar os produtos descrevendo-os pormenorizadamente, mas agora podendo mostrá-los, acariciá-los em frente ao espectador: "não é uma tentação?"2. Os primeiros programas patrocinados da televisão costumavam levar o nome do anunciante, sendo que este comprava o espaço e se responsabilizava pela sua produção. A partir dos anos 70 é que a programação vai ser assumida exclusivamente pelas emissoras, sem vincular o anunciante ao nome do programa (Ramos, Marcondes, 1995). Por um lado, isso ajudou a demarcar as especificidades da produção televisiva e da publicitária - que não se esgota na televisão. Por outro lado, distanciou por demais o patrocinador, eximindo-o, de certa maneira, da responsabilidade social pela qualidade da programação que financia.

Embora o meio publicitário - e o mercado - tenham assumido definitivamente a criança como espectador/consumidor entre as décadas de 70 e 80 , sua

2. Bordão utilizado por Rosamaria, garota-propaganda de Marcel Modas, que apresentava o quadro "Tentação do dia", nos anos 50 e 60. 
imagem, desde há muito, já é figura constante da publicidade. Fazendo uso da imagem da infância, a publicidade tanto oferece produtos destinados a ela (brinquedos, roupas, doces, parques de diversão etc.) como também oferece produtos típicos do mundo adulto (locação de veículos, venda de automóveis, amaciante de roupas, cadernetas de poupança, seguros de vida etc.), num discurso dirigido ao adulto, porém, mediado pelos discursos que o mundo adulto construiu sobre a infância. Nessa perspectiva, encontramos tanto os anúncios que utilizam a criança como protagonista quanto os que elegem a criança como interlocutor ou mediador para o "convencimento" de seus pais. Recorrer à imagem da infância é, muitas vezes, um recurso de ilustração a um discurso no qual a própria criança não é reconhecida como sujeito. Exemplo disso é a crença recorrente no meio publicitário de que

...existem três apelos muito grandes que, por darem certo, acabam surgindo constantemente nas mensagens: animal, criança e sexo. E criança, especialmente, carrega, além do apelo emocional, o peso de um senso comum, a respeito de que a criança é verdadeira, inocente, o que acrescenta à mensagem uma grande dose de credibilidade. (Giacomini Filho apud Pacheco, 1998, p. 145) 3

Que lugar é esse no qual a criança tem espaço cativo? Que outras questões estão implicadas na suposta conquista desse lugar? $\bigcirc$ que essas mudanças nos contam sobre as transformações mais amplas acontecidas na dinâmica social, especificamente na relação entre adultos e crianças? Como podemos relacioná-las com outras esferas da produção cultural - as diversas formas de arte, sejam elas dirigidas ao público infantil ou não? Que exigências estéticas têm orientado nosso cotidiano? É no bojo dessas indagações que se coloca a urgência de construção de bases teórico-metodológicas sólidas para as pesquisas sobre a relação entre criança e televisão e publicidade. Assim como no caso da televisão, também no que se refere à publicidade as críticas produzidas têm sido marcadas por algumas controvérsias, principalmente no que diz respeito à origem das questões formuladas. Serpa ( 1 999) classifica dois tipos de crítica existentes hoje envolvendo o tema da publicidade. Uma delas acontece no interior do sistema e tem caráter pragmático e formal; a outra, acontece fora do sistema, operada pelo "leigo" e tem sido, segundo o autor, equivocada. $\bigcirc$ equívoco apontado por Serpa está em que "o

3. Originalmente a citação remete a Silveira, 1985. 
leigo tem uma tendência a analisar o anúncio do ponto de vista da crítica de arte, da crítica de expressão, posicionamento que pouco tem a ver com a razão de ser da propaganda - que está na consecução do efeito desejado" (। 999, p. 8I, nota 6).

Esse suposto hiato entre o sistema de produção e os modos de compreensão do espectador acaba por fomentar dogmas e maniqueísmos que, longe de contribuir para a construção de uma crítica efetiva, fragmentam ainda mais as relações sociais implicadas no campo da comunicação, naturalizando seu caráter imperativo. Desse modo, tanto a instância crítica reduzida unicamente ao interior do próprio sistema quanto a crítica externa - elaborada sem levar em consideração o que é específico ao sistema - são insuficientes para esboçar o necessário diálogo entre os produtores da comunicação publicitária e os demais segmentos da sociedade. Cindindo as esferas da produção e da recepção televisivo-publicitária, torna-se impossível a elaboração de uma crítica que contemple as contradições e as demandas sociais desse campo do saber. Nessa linha de pensamento é que as reflexões trazidas por Mikhail Bakhtin e Oliviero Toscani representam uma significativa contribuição para a construção de uma perspectiva metodológica de pesquisa.

\section{AS IMAGENS DE TOSCANI E O OLHAR DE BAKHTIN}

O objetivo desta reflexão é o de construir um mapeamento inicial das questões centrais que norteiam a análise bakhtiniana, a fim de buscar elementos que ajudem a construir uma metodologia para compreender um outro tipo de produção cultural: a publicidade. Para tanto, busca-se um diálogo com o fotógrafo/publicitário Oliviero Toscani, responsável pela criação publicitária dos polêmicos anúncios da Benetton ${ }^{4}$, cujas indagações lançadas à produção publicitária guardam muitas interfaces com as reflexões suscitadas por Bakhtin. Buscar um diálogo entre autores e obras com diversificadas questões, originadas em espaços e tempos diferenciados, é uma tarefa um tanto paradoxal. Por um lado, não há como não questionar as conseqüências de se buscar um referencial teórico específico para encaminhar questões que originalmente não compunham as inquietações do autor. Por outro lado, o fato de os autores/produtores envolvidos postularem a necessidade de abertura das obras e reservarem aos leitores/espectadores um papel ativo, que os transforma em co-criadores dessa obra, permite uma certa tranqüilidade à

4. Em maio de 2000, o fotógrafo/publicitário deixou de exercer essa atividade específica. 
medida que esses postulados se convertem em autorização para a construção de outros textos e intertextos, ou, no dizer de Bakhtin:

Não existe nem a primeira nem a última palavra e não existem fronteiras para um contexto dialógico (ascende a um passado infinito e tende para um futuro igualmente infinito). Inclusive os sentidos passados, ou seja, gerados nos diálogos dos séculos anteriores, nunca podem ser estáveis (concluídos de uma vez para sempre, terminados); sempre vão mudar, se renovando no processo posterior do diálogo. Em qualquer momento do desenvolvimento do diálogo existem as massas enormes e ilimitadas de sentidos esquecidos, porém, nos momentos determinados do desenvolvimento posterior do diálogo, no processo, serão recordados e reviverão em um contexto e num aspecto novo. Não existe nada morto de uma maneira absoluta: cada sentido terá sua festa de ressurreição. Problema do grande tempo. (1982, p.223, tradução nossa)

Cabe frisar que, resguardadas a historicidade dos conceitos e a atualidade dos constructos teóricos de Bakhtin, o que em sua obra se torna mais caro às indagações aqui expostas é a dimensão política do olhar que lança à realidade, imprescindível à instância crítica. Ainda, recorrer à critica que o autor tece em torno do campo da arte mostra-se como caminho bastante fecundo para subsidiar a reflexão sobre o contexto histórico em que vivemos, no qual a própria arte assume um novo estatuto diante da lógica mercantil.

Bakhtin reivindica que a reflexão sobre a arte siga os pressupostos do método sociológico - em sua acepção marxista - como premissa para que a arte seja reconhecida na sua condição de produção social, haja visto que ela "se torna arte apenas no processo de interação entre criador e contemplador, como fator essencial nessa interação" (1 976, p.6, trad. Cristóvão Tezza, para uso didático). Tal reivindicação deveu-se ao fato de que as clássicas análises sobre a arte operavam tendo como ponto de partida o isolamento de seus elementos constitutivos: a obra, o artista e o contemplador. Inseridas na tradição dualista que opõe sujeito e objeto, as teorias sobre a arte viriam tangenciando esses dois pólos, favorecendo ora a um, ora a outro. Se é tratada unicamente como "obra", sem levar em consideração suas relações de produção e recepção, acaba por reduzir-se a artefato. Dessa compreensão objetivista, resulta o que Bakhtin nomeou como fetichização da obra de arte, concepção buscada na tradição marxista, e sua crítica ao fato de atribuirmos aos objetos do mundo material características que são próprias do homem e das suas relações sociais. No caso específico da arte, implicaria a total autonomia da arte, como objeto de arte diante do seu produtor, seu receptor e às relações so- 
ciais. Sob o outro ponto de vista, encontra-se uma postura subjetivista, que, ao contrário da primeira, restringe a análise da arte às experiências psíquicas de seu produtor ou receptor. Dessa maneira, retira-a também do contexto social, à medida que a reduz a produto de uma experiência individual.

Para Bakhtin, ambos os pontos de vista são insuficientes exatamente por pretenderem, isolados em seus respectivos ângulos, dar conta da arte como um todo. Com isso, o que conseguem é empobrecer o potencial de seus elementos constitutivos, bem como as teorias sobre a arte. Diz Bakhtin que o que confere a condição de arte a um tipo de produção humana

...não se localiza nem no artefato nem na psique do criador e contemplador considerados separadamente; ele contém todos esses três fatores. $O$ artístico é uma forma especial de inter-relação entre criador e contemplador fixada em uma obra de arte. (1976, p.5, trad. Cristóvão Tezza, para uso didático)

Bakhtin afirma que a comunicação estética deriva de uma base social comum, da qual também derivam outras formas de produção - a exemplo da política, da jurídica, da moral, da ciência etc. e seus respectivos gêneros discursivos -, sendo que sua identidade é conferida pela singularidade com que se relaciona com essa base comum. $\bigcirc$ que caracteriza a comunicação estética é o fato de que "ela é totalmente absorvida na criação de uma obra de arte e nas suas contínuas recriações por meio da co-criação dos contempladores e não requer nenhum outro tipo de objetivação" (Bakhtin, 1976, p.6, trad. Cristóvão Tezza, para uso didático). É uma forma única que, por isso mesmo, não existe isoladamente, mas participando do "fluxo unitário da vida social", em permanente troca com outras formas de comunicação.

Entre as variadas formas de comunicação, Bakhtin dirige seu olhar para a comunicação estética e, nesta, mais especificamente, para a forma artística - a literatura e, em especial, a poética. No entanto, o autor pondera que, para compreender os enunciados específicos do campo da arte, se torna necessário buscar auxílio em outras esferas da produção humana - o que inclui a vida cotidiana - pois os enunciados originados nessas outras esferas já contêm em germe a forma artística, uma vez que a arte dialoga com outros campos da produção (Stam, 1992). Bakhtin ( 1985 ) contrapõe duas concepções de unidade artística, uma mecânica e puramente formal, que admite que as diferentes áreas da cultura humana e seus elementos se relacionam entre si ligadas por uma relação puramente externa; outra, conceitual, entendendo que essas áreas cobram uma unidade que é permitida pela atividade 
arquitetônica da mente, ainda que aparentemente se mostrem distanciadas. Essa unidade é dada pela atribuição de sentidos, isto é, pela implicação dos sujeitos diante das produções da sua cultura. A atribuição de sentidos resulta de um processo interior da consciência humana, sendo que, para o autor, ela própria, a consciência, é uma construção social (Bakhtin, 1985; Stam, 1992).

Exemplificando as distintas concepções, Bakhtin traz para o debate as relações entre a arte, a ciência e a vida, três áreas da cultura humana que nos permitem compreender as questões éticas e políticas implicadas com as maneiras que se relacionam entre si. Se a produção da arte se afasta da produção da vida cotidiana, o próprio sujeito humano torna-se cindido entre o homem comum e o artista; assim, "se o homem se encontra na arte, não está na vida", e vice-versa, tornando a vida e a arte mecanicamente distintas e autônomas. Ao artista caberia a recriação do mundo pela via da inspiração, sem precisar responder pelos qüiproquós da vida cotidiana; ao homem comum caberia, nesse caso, levar a vida cotidiana, sem ter de responder pela criação. A mesma crítica caberia à produção científica nas suas formas de se relacionar com a vida e com a arte - crítica essa que Bakhtin assume tanto ao propor uma análise sociológica da arte quanto ao fazer, junto disso, uma análise crítica da própria Sociologia.

Uma das conseqüências éticas dessa visão mecanicista, diz Bakhtin, é o empobrecimento das próprias esferas específicas da cultura humana e, com isso, da compreensão que o homem constrói de si mesmo e do outro. Por isso, a necessidade de buscar essa unidade que é permitida pela responsabilidade, isto é, pela implicação ética do homem diante de suas atitudes. É na unidade da responsabilidade/respondibilidade, isto é, na tomada de postura em relação às demandas da vida social que o homem constrói sentidos e estabelece os vínculos de unidade entre as diversas áreas da cultura. Ou seja, é no interior da unidade da responsabilidade que se imbricam a arte, a ciência e a vida. Diz Bakhtin que "devo responder com minha vida por aquilo que é compreendido na arte, para que todo o vivido e compreendido não permaneça sem ação na vida". Diz ainda que a responsabilidade se relaciona também com a culpa. Certamente "é mais fácil criar sem se responsabilizar pela vida", do mesmo modo que é mais fácil viver sem levar em conta a arte. No entanto, uma vez admitida a cisão entre a arte e a vida, é preciso culpar-se, seja pela negação da sensibilidade ao homem comum, seja pela negação ao artista pelo agir circunstancial do cotidiano. Do mesmo modo, cabe ao artista e ao homem comum assumirem sua responsabilidade perante a arte e a vida, pois "um poeta deve recordar-se de que sua poesia é culpada pela trivialidade da vida, e o homem na vida há 
de saber que sua falta de exigência e seriedade em seus problemas existenciais é culpada pela esterilidade da arte" (Bakhtin, 1985, tradução nossa).

Ao ponderar acerca da unidade entre as distintas áreas da cultura humana, em hipótese alguma Bakhtin está postulando a existência de uma homogeneidade entre elas. Ao contrário, cada área da cultura tem sua especificidade e é essa pluralidade que garante a riqueza da existência humana. Essas somente se convertem em algo unitário na unidade da responsabilidade, na atribuição de sentidos, na tomada de postura por parte de cada um. Responder é colocar-se diante do "outro" e, ao mesmo tempo, recriar-se. É preciso ponderar também que o conceito de "responsabilidade" cunhado por Bakhtin está intimamente associado à sua concepção de "autoria". Para o autor, toda criação é, por natureza, coletiva, uma vez que a própria vida humana é uma construção que ocorre dá na fronteira entre o "eu" e o "outro". Toda criação ou toda compreensão é sempre fruto de um diálogo, sempre parte de uma relação de alteridade, de um contexto em que os "eus" são autores uns dos outros, co-autores das suas produções. A "autoria" é também criação de si mesmo, posto que o self não existe fora do dialógico, é permanente presença do outro: o eu precisa daquilo que o outro vê. Dessa maneira, Bakhtin rejeita veementemente o conceito de "indivíduo" trazido à tona pelo ideário capitalista, insuficiente para pensar a complexidade da realidade social, porque comprometido com uma injusta divisão social do trabalho, do saber, da criação, da recepção, da sensibilidade. Exemplo disso, no contexto capitalista, o conceito de produção é visto como posse, e o conceito de contemplação, visto como não-trabalho, não-produção.

As reflexões de Oliviero Toscani em muito se aproximam dos conceitos trazidos por Bakhtin. Segundo Toscani (1996a), há urgência em se formularem questões que visem recolocar em novas bases a relação da publicidade com a arte. É preciso que se lance um olhar político para a publicidade, haja vista que esta se tornou uma instituição de inegável poder, formadora de subjetividade. $\bigcirc$ que, de fato, a publicidade comunica? Que outras formas comunicativas são possíveis à publicidade? $\bigcirc$ que, efetivamente, está a criar? Como se relaciona com as demais áreas da cultura humana e com os sujeitos que a produzem e a recebem? Procurando dar visibilidade à dimensão política que a publicidade tem, Toscani denuncia, tendo como referência a realidade italiana, que a despesa com a propaganda de produtos é maior que os investimentos estatais em educação. Pondera que sua tese é um pouco difícil de ser comprovada, uma vez que, mesmo se orgulhando do per capita que movimentam, os órgãos responsáveis pela regulamentação publicitária ou outros órgãos competentes jamais diriam que "a despesa com publicidade na 
Itália é igual à despesa para a pesquisa industrial, maior que os investimentos estatais destinados à educação e infinitamente superior aos investimentos na saúde pública" (Toscani, 1996a, p. 50).

Toscani, com seu trabalho, reivindica um outro lugar para a produção publicitária. Em outdoors, revistas, jornais e catálogos apresenta diferentes imagens, assinadas pelo slogan "United Colors of Benetton": negros, brancos, orientais, ocidentais, portadores de necessidades especiais, condenados à pena de morte, crianças recém-nascidas, roupas de soldados mortos, doentes em fase terminal, tabus, preconceitos, utopias. Independentemente de tecer juízos de valor acerca do seu nível de comprometimento com o mercado, é explícita a sua reivindicação de que a publicidade resgate sua dimensão artística. As polêmicas que suscita com as imagens que veicula apresentam-se como uma metalinguagem de um papel que entende ser também o da publicidade: deter-se sobre os problemas da realidade humana.

Qualquer imagem publicitária, mesmo a mais idiota, tem uma significação sociopolítica. Não há imagens que não tenham uma mensagem, uma significação. As imagens que projetam imagens de supermodelos, de supermentiras, são de qualquer forma, imagens sociopolíticas. [...] Minhas imagens não são diferentes, desse ponto de vista. Só que elas andam com a realidade do mundo. [...] São realidades humanas. (Toscani apud Calligaris, 1996, p. 76)

Tais ponderações aproximam-se, de certa maneira, da reivindicação bakhtiniana de que a arte fosse reconhecida como produção social. Nesse sentido, a crítica de Bakhtin ajuda-nos a formular um outro olhar para a publicidade. Orientados por sua reflexão, podemos afirmar que a comunicação publicitária deriva de uma base social comum, da qual também derivam outras formas de produção - a arte, a política, a ciência etc.

A realidade social que produz carros, pulôveres, cremes de beleza é a mesma que produz o preconceito, a aids. A indústria que produz esses produtos e a empresa que faz a comunicação dessa indústria também produz realidade - e desigualdade social. [...] Mas procure o espectador encontrar numa propaganda de nossos dias pobres, imigrantes, acidentados, revoltados [...], desastres ecológicos, explosões da juventude e o pânico dos idosos! Foi tudo substituído por Claudia Schiffer. ${ }^{5}$

5. Fragmento transcrito de Entrevista concedida por Oliviero Toscani ao Programa Roda Viva, da TV Cultura, em 17.5.95, publicada parcialmente na Folha de S. Paulo, Caderno Mais! de 30.5.95. 
fato de a publicidade consolidar-se como um hegemônico discurso de adesão ao consumo, bem como promessa de um mundo idílico, longe de ser naturalizado, precisa ser revisto sob uma outra ótica, que não desconsidere a dimensão política da realidade social. Urge, portanto, que lancemos a ela um olhar crítico, que nos permita compreender essas interfaces. Nesse sentido, Toscani complementa:

Coloco-me perguntas, penso que tudo está ligado. Não existe uma oposição clara: monocultura ou pluricultura. Há McDonald's e há culturas sem McDonald's. No meio, há nós. [...] Não há sociedades isoladas. A humanidade é uma só, há quem compra e há quem morre de Aids, quem é canalha e quem não é, e, muito freqüentemente, estão no mesmo elevador. E não entendo como poderia haver expressões, sobretudo artísticas, que sejam destacadas disso. (Toscani apud Calligaris, 1996, p.84)

Construir um outro discurso publicitário, que vise ao questionamento da realidade humana, é visto por Toscani como possibilidade de recuperação da dimensão artística da publicidade, uma metodologia de trabalho que se apresenta como forma de resistência ao padrão existente:

...estimular uma discussão crítica no interior da comunicação publicitária; introduzir imagens de realidade num sistema que tem, ou teve, o imperativo categórico de desnaturar a realidade, falsificando-a, tornando-a mais bela, eliminando os conflitos existentes. [...] É bom suscitar dúvidas em vez de concordar com o conformismo das certezas. Quando muitos me perguntam o que têm a ver a guerra, o nascimento ou a morte com a venda de malhas, respondo que nada. Mas não é totalmente exato. Creio que há cada vez mais gente disposta a discutir sobre os problemas sociais que a inquietam sem por isso deixar de comprar, até com certo prazer voluptuoso, uma roupa bem-feita, de boa qualidade, honesta no preço. (Toscani, 1996, p. 59-60)

Com isso, Toscani pondera que é necessário construir uma crítica da publicidade para além de sua aparência formal, isto é, que permita analisá-la levando em consideração sua qualidade técnica, mas também os sujeitos implicados com sua produção e recepção. Cabe ao publicitário responder às exigências da realidade social, denunciando o lugar-comum em que a publicidade se transformou, pois 
....se o lugar-comum é denunciado com consciência, talvez seja mais fácil superá-lo. As discussões partiram desse ponto. Descobri que o lugar-comum, que deveria ser algo a que estamos acostumados, não é na realidade um dado adquirido. E que possui uma força revolucionária, rompedora. (Toscani, 1996a, p.6I)

Tomando como exemplo o tipo de publicidade que vende um creme de beleza, prometendo à consumidora que o seu uso a deixará tão bela quanto a garota-propaganda, ou a que vende virilidade associada à posse de um determinado modelo de carro, Toscani questiona a responsabilidade do publicitário para com a sua produção e os "consumidores" das imagens que produz. Acusa os publicitários de abdicarem da atividade criadora, em prol da administração da "boa idéia", desempenhado pelo chamado "diretor de criação". Cobra, ainda, que se responsabilizem pela construção de modos de ser - sobretudo dos jovens - seduzidos por valores difundidos em produções medíocres:

A publicidade é hoje mais formadora de nossa subjetividade do que o ensino escolar. Ela é a maior expressão de nossa época, quantitativamente pelos investimentos que mobiliza, e qualitativamente por seu protótipo cultural, pois o consenso da razão contemporânea parece ser feito de imagens de sonho que nos convidam: "sejam como nós, imagens publicitárias". (Toscani apud Calligaris, 1996, p. 89)

Toscani traz para o debate a necessidade de se colocarem em questão as conseqüências éticas do trabalho do publicitário diante da realidade social. Do mesmo modo que o arquiteto nos ensina a habitar nossa casa, que o cineasta nos ensina a olhar, também o publicitário precisa ter consciência da dimensão educativa da sua profissão. Do mesmo modo, a publicidade precisa ser objeto de indagação de quem a recebe - ainda que o espectador mostre sua resistência aproveitando a hora dos "comerciais" para fazer outras atividades. O consumidor precisa exigir uma publicidade de qualidade, mas, para isso, é necessário que seja educado para tal. Toscani menciona, como exemplo dessa necessária tomada de postura, reações e boicotes motivados inclusive pela publicidade assinada por ele, a exemplo, principalmente, da campanha em torno dos condenados à pena de morte por crimes ditos hediondos.

Eu penso que precisaria ensinar a ler a publicidade e em geral a nova comunicação. Hoje a leitura não só são os livros. Os professores, aliás, deveriam se especializar em comunicação moderna. Precisa saber ler a televisão e ninguém ensina isso, quando deveria ser um dos primeiros ensinos, na própria escola maternal, ensinar a ler 
imagens. Parece-me muito claramente que hoje as imagens são a realidade. Mais de $90 \%$ do que conhecemos, conhecemos por imagens. Temos opiniões sobre coisas que só conhecemos por imagens. (Toscani apud Calligaris, 1996, p. 85)

A preocupação de Toscani em colocar a realidade humana em questão é complementada pela afirmação de que esse questionamento precisa ser compartilhado pelo publicitário - que precisa ter consciência daquilo que produz e saber efetivamente o que pretende comunicar - e pelo espectador - que deve recusar um modelo de publicidade que não o reconheça como sujeito crítico. Nesse sentido, pode-se perceber uma outra interface com o pensamento bakhtiniano, em torno do conceito de responsabilidade, tanto no que se refere à tomada de postura política do produtor ou receptor diante da obra publicitária, quanto na recomendação de que se busque criar um outro tipo de comunicação publicitária, que, colocando em questionamento a realidade humana, se transforme numa obra/produção a ser complementada pelos seus contempladores e na relação com outros tipos de produção, sendo recriada no dialogismo.

Um ponto positivo nessa busca de um outro olhar e de outras condições de produção/recepção, para a publicidade, é o fato de que esta começa a ocupar, efetivamente, outros lugares. Transcendendo os limites do intervalo dos programas, passaram a ser tema central de muitos programas. A história da propaganda tem-se apresentado cada vez mais como uma forma reconhecida de memória social. Também muitas imagens e catálogos tornaram-se objetos de exposição em museus e feiras de arte. Extrapolando seu espaço original, a publicidade tem construído alguns diálogos com outras áreas da cultura. Investigar os sentidos que permeiam esses diálogos é tarefa a ser assumida também pelos pesquisadores e educadores da infância contemporânea. Fundar um debate contundente em torno da mídia - e, especificamente, da publicidade televisiva -, é pressuposto básico para reinvenção de uma postura crítica diante dela, na família, na escola, nos diferenciados espaços sociais.

\section{REFERÊNCIAS BIBLIOGRÁFICAS}

ANDRADE, C. D. O Corpo. Rio de Janeiro: Record, 1994. Eu Etiqueta.

ARIÈS, P. História da vida privada 3: da Renascença ao Século das Luzes. São Paulo: Companhia das Letras, 1993. p. 7-19: Por uma história da vida privada.

História social da criança. Rio de Janeiro: Guanabara, 1981. 
BAKHTIN, M. Estética de la creación verbal. México: Siglo XX, 1985.

. Estética de la creación verbal. Buenos Aires: Siglo Veintiuno, 1982.

- [Volochinov, V.] Freudianism: a marxist critique. New York: Academic Press, 1976.

Discourse in life and discourse in art: concerning sociological petics.

BAUDRILLARD, J. A Sociedade de consumo. Lisboa: Edições 70, 1995.

- À sombra das maiorias silenciosas: o fim do social e o segmento das massas. São Paulo: Brasiliense, 1993.

BAZALGUETE, C.; BUCKINGAN, D. In Front of the children: screen entertainment and young audiences. Londres: British Film Institute, 1995.

BENJAMIN, W. Obras escolhidas. São Paulo: Brasiliense, 1987. v. I: Arte e política; magia e técnica.

. Reflexões: a criança, o brinquedo, a educação. São Paulo: Summus, 1984.

BUCCI, E. Brasil em tempo de TV. São Paulo: Boitempo, 1997.

BROUGÈRE, G. Brinquedo e cultura. São Paulo: Cortez, 1995.

CALLIGARIS, C. Crônicas do individualismo cotidiano. São Paulo: Ática, 1996. p. 73-92: Entrevista com Toscani.

CARLSSON, U.; VON FEILITZEN, C. (orgs.). A Criança e a mídia: imagem, educação, participação. São Paulo: Cortez; Unesco, 2002.

GARCIA, C. et al. Infância, cinema e sociedade. Rio de Janeiro: Ravil, 1996.

GUATTARI, F. Revolução molecular: pulsações políticas do desejo. São Paulo: Papirus, 1987. FANUCCHI, M. Nossa próxima atração. São Paulo: Edusp, 1995.

FLUSSER, V. Ensaio sobre a fotografia: para uma filosofia da técnica. Lisboa: Relógio D'água, 1998.

HAMBURGUER, E.; BUCCl, E. A TV aos 50: criticando a televisão brasileira no seu cinqüentenário. São Paulo: Fundação Perseu Abramo, 2000.

HOINEF, N. A Nova televisão. Rio de Janeiro: Relume-Dumará, 1995.

JAMESON, F. Pós-modernismo: a lógica do capitalismo tardio. São Paulo: Ática, 1996.

KEHL, M. R. Imaginar e pensar. In: NOVAES, A. (org.). Rede imaginária. São Paulo: Companhia das Letras, 1991. p. 60-72. 
. Televisão e violência do imaginário. In: HAMBURGUER, E.; BUCCI, E. A TV aos

50: criticando a televisão brasileira no seu cinquëntenário. São Paulo: Fundação Perseu Abramo, 2000.

KEHL, M. R.; CALLIGARIS, C.; SEVCENKO, N. A Sedução dos jovens. Folha de S. Paulo. Caderno Mais, 20 set. 1998.

KINCHELOE, J. Esqueceram de mim e Bad to the bom: o advento da infância pós-moderna. In: STEINBERG, S.; KINCHELOE, J. (org.). Cultura infantil : a construção corporativa da infância. Rio de Janeiro: Civilização Brasileira, 200 I . p. 53-86.

LIPOVETSKY, G. O Império do efêmero. São Paulo: Companhia das Letras, 1999.

MARTINS, M. H. Outras leituras: literatura, televisão, jornalismo de arte e cultura e linguagens itinerantes. São Paulo: Editora Senac; Itaú; Cultural, 2000.

MOREIRA, R. Vendo a televisão a partir do cinema. In: HAMBURGUER, E.; BUCCI, E. A TV aos 50: criticando a televisão brasileira no seu cinquëntenário. São Paulo: Fundação Perseu Abramo, 2000.

MORENO, L. K. Televisão: a babá nossa de cada dia. Jornal da USP, p. 6, 9/15 mar. 1992.

PACHECO, E. Televisão, criança, imaginário, educação. São Paulo: Papirus, 1998.

PASOLINI, P. P. Os Jovens infelizes: antologia de ensaios corsários. São Paulo: Brasiliense, 1990.

POSTMAN, N. O Desaparecimento da infância. Rio de Janeiro: Graphia, 1999.

RAMOS, R.; MARCONDES, P. 200 anos de propaganda no Brasil: do reclame à cyberanúncio. São Paulo: Meio e Mensagem, 1995.

RIXA. Almanaque da TV: 50 anos de memória e informação. Rio de Janeiro: Objetiva, 2000.

ROCHA, E. A Sociedade do sonho: comunicação, cultura e consumo. Rio de Janeiro: Mauad, 1995.

SAMPAIO, I. S. Televisão, publicidade e infância. São Paulo: AnnaBlume, 2000.

SARLO, B. Paisagens imaginárias. São Paulo: Edusp, 1997.

SERPA, M. N. A Identidade na propaganda: uma análise do caso brasileiro. ECO, v. 4, n. I, p. 81-87, 1999.

SILVEIRA, J. X. A Criança possui um sentido lúdico. Meio e Mensagem, n. I84, p. 7, nov. 1985.

SOUZA, S. J. O Olho e a câmera. Papéis Avulsos. 200 I. Disponível em: < www.gips.psc.br> 
. (org.) Subjetividade em questão: a infância como crítica da cultura. Rio de Janeiro: 7Letras, 2000.

STAM, R. Bakhtin: da teoria literária à cultura de massa. São Paulo: Ática, 1992.

TOSCANI, O. A Publicidade é um cadáver que nos sorri. São Paulo: Ediouro, 1996. . Tchau, mãe! Rio de Janeiro: Revan, 1996a.

WOLTON, D. Elogio del gran público: una teoria crítica de la televisión. Barcelona: Editorial Gedisa, 1990. 
